\title{
Foreign Aid in Nepal
}

\author{
Kiran Bahadur Pandey \\ Associate Professor of Economics \\ Patan Multiple Campus, Tribhuvan University ,Nepal
}

\begin{abstract}
Fore aid is essential for least developed countries like Nepal because these countries have the shortage of fund to meet their domestic investment for accelerating economic development and also to finance the import of essential capital goods required for the development. Nepal receives foreign aid from bilateral and multilateral sources. Following a descriptive approaches this paper analyses the trend of foreign did flow in Nepal from aggregative perspective.
\end{abstract}

Key words: Foreign aid, grant and loan, least developed countries, Nepal

\section{BACKGROUND}

Literally, foreign aid simply refers to resources given by developed countries and international organizations to support the economic, sociological and political development of developing countries. It is transfer of resources from developed countries for the purpose of encouraging economic growth in developing countries with the promotion of the economic development. However, all types of resource transfer cannot be considered as foreign aid. The foreign aid should have certain features such as it should be with aim of economic development, welfare of recipient country and should have grant element, low interest rate and supportive for long term capital requirement. Foreign aid enables the developing economy to achieve the objective of technological up-gradation and innovations and helps to meet the gap between investment needed and saving (Lekhi, 2005). Besides, it overcomes not only capital deficiency and technological backwardness but also brings skilled personnel, organizational experience, market information advanced production techniques, innovations etc.

Foreign aid has been recognized as the most crucial factor in enhancing economic development in many countries. No doubt, it is extremely fruitful for developing countries such as Nepal as well, which lack enough capital and technological resources necessary for higher investment and development. 


\section{TREND OF FOREIGN AID IN NEPAL}

The four point program agreement signed between Nepal and the US on 23 January, 1951 heralded Nepal's first experience of foreign aid assistance. The US government's assistance of Rs. 22,000 provided under four point program. Nepal received foreign assistance mainly in the form of grants and loans. In the 1960's and 70's, Nepal received foreign aid mainly through grants. Grants made up almost 70\% of total foreign aid. However, the composition of aid changed significantly when she asked to borrow. In $2000 / 01$, Nepal received $64.07 \%$ in the form of loan and $35.93 \%$ in the form of grants (Sigdel, 2004).

Again, the situation has been changed in 2009/10, grants shares was $77.4 \%$, while loans was $22.6 \%$. The current situation shows that amount of loan is increasing and amount of grants is decreasing. In Nepalese context, loans are mainly from multilateral sources like IMF, WB and ADB etc. while grants are received from IMF, WB and ADB etc., while grants are from bilateral sources.

The table shows the share of loan and grant in foreign aid in the process of economic development of Nepal .UP to 1970, foreign aid flow to Nepal confined to diminutive size. During the period 1950-70, bilateral grant played a predominant role in the structure of foreign aid in Nepal. During 1980s and 90s assistance was rapidly increased which was provided by the multilateral financial institutions like ADB, IDA and other UN agencies. However, the composition of aid changed significantly when she asked to borrow. In 2000/01, Nepal received $64.07 \%$ in the form of loan and 35.93\% in the form of grants.Again, the situation has been changed in 2009/10, grants shares was $77.4 \%$, while loans was $22.6 \%$. The current situation shows that amount of loan is increasing and amount of grants is decreasing. Trend of Foreign Aid in Nepal is given in Table 1. 
Table 1: Trends of Foreign Did in Nepal

(Rs.in million)

\begin{tabular}{lccc}
\hline Fiscal years & Grant & Loan & Total Foreign Aid \\
\hline $1950 / 51$ & 1.01 & - & 1.01 \\
$1951 / 52$ & 1.01 & - & 1.01 \\
$1955 / 56$ & 1.01 & - & 1.01 \\
$1956 / 57$ & 1 & - & 1 \\
$1962 / 63$ & 128.36 & - & 128.36 \\
$1963 / 64$ & 125 & 13.44 & 138.44 \\
$1970 / 71$ & 270.69 & 32.46 & 303.14 \\
$1980 / 81$ & 993.3 & 729.9 & 1723.2 \\
$1990 / 91$ & 1630 & 4360 & 5990.0 \\
$2000 / 01$ & 6753.4 & 12044 & 18797.4 \\
$2005 / 06$ & 19574.8 & 6162.70 & 2537.5 \\
$2007 / 08$ & 20320.72 & 8979.87 & 29300.59 \\
$2008 / 09$ & 26328.86 & 99688.61 & 36297.74 \\
$2009 / 10$ & 38545.97 & 11223.38 & 49769.35 \\
$2010 / 11$ & 45922.17 & 12075.60 & 57997.77 \\
$2011 / 12$ & 40810.28 & 11083.07 & 51893.35 \\
$2012 / 13$ & 35229.80 & 11969.44 & 47199.24 \\
$2013 / 14$ & 42205.7 & 17998.82 & 60204.52 \\
\hline
\end{tabular}

Sources: various economic surveys, $\mathrm{MOF}$

\section{WHY FOREIGN AID?}

Foreign aid playsan important role in Nepal's development. Foreign aid is crucial to meet the objectives of poverty reduction as articulated in the various recent government three year plan. In the context of Nepalese economy, which is characterized by structural bottlenecks, large fiscal and external deficit and significant imbalance between saving and investment ratios, the role of foreign aid may significant. On the other hand, the role of foreign aid in the process of economic development of Nepal cannot be ignored due to resources constraints.

Since, saving gap increases when domestic savings rate is less than the investment required to achieve the targets. For example, if the growth target of national real 
income is $6 \%$ per annum and the capital output ratio is 4.5 , then economy must save $27 \%$ of its national income to achieve the target of growth. But, we can mobilize only about $8 \%$ of saving domestically the saving gap is $19 \%$ of national income. Thus, in our context, foreign aid may be crucial.

Foreign aid has its role to promote the transfer of technology or knowledge which accelerate production and productivity of the economy, which is one of the basic conditions for achieving the poverty alleviation objective and infrastructural development. Besides, foreign aid is useful instrument to meet foreign exchange gap, financial needs of crisis period and financial requirements for yearly budget and development plans.

Since, Nepal has not been successful in attracting FDI as expected, because of internal factors such as prolonged political instability and lack of investment friendly environment. In this context, foreign aid helps to create environment for attracting foreign direct investment and promoting private sector investment. The contribution of foreign aid in the development of Nepal is shown in Table 2.

Table 2: The Contribution of Foreign Aid in Periodic Development Plans of Nepal (RS. in million)

\begin{tabular}{lcc}
\hline Plan Period & Development Expenditure & Foreign Aid \\
\hline $1^{\text {st }}$ plan & 389.2 & 389.2 \\
$2^{\text {nd }}$ plan & 617.7 & 478.5 \\
$3^{\text {rd }}$ plan & $1,639.1$ & 919.8 \\
$4^{\text {th }}$ plan & $3,356.9$ & $1,509.1$ \\
$5^{\text {th }}$ plan & $8,870.6$ & $4,264.1$ \\
$6^{\text {th }}$ plan & 21,750 & 13,260 \\
$7^{\text {th }}$ plan & $48,345.4$ & $23,978.5$ \\
$8^{\text {th }}$ plan & $111,918.8$ & 49,203 \\
$9^{\text {th }}$ plan & $2,151,454.4$ & 111,546 \\
$10^{\text {th }}$ plan & $16,200.25$ & $9,131.25$ \\
$11^{\text {th }}$ plan & $65,524.5$ & $36,139.1$ \\
$12^{\text {th }}$ plan & $17,584.28$ & $9,354.88$ \\
\hline
\end{tabular}

Sources: Various periodic plans, national Planning Commission (NPC) \&various economic surveys, Government of Nepal, Ministry of Finance (MOF). 
Table 2 shows the role of foreign aid in periodical plans of Nepal. The developmental expenditure in each periodic plan was heavily financed by foreign aid. This show the role of foreign aid is supplement and enhance Nepal's meager domestic saving so as to mobilize increasing resources for poverty alleviation.

\section{CHALLENGES}

According to foreign aid policy 2009, the main objective of accepting foreign assistance is to utilize the foreign assistance effectively such that country can reduce poverty through a high, inclusive and sustainable economic growth. However, the aid absorptive capacity of Nepal is found to be poor. The inadequate infrastructure, complexity of public procurement act, prolonged bureaucracy procedures in finalizing project and administrative inefficiency are the major factors for poor capacity of spending foreign aid. The complicated procedures in finalizing things, lack of ownership and leadership, lack of coordination, finding suitable contractors and poor institutional capacity appear to be the major hurdles in the timely completion of the foreign aided projects. In addition, the priorities of donors their interest and complexities have also been attributed to low absorptive capacity of aid in Nepal.

However, all types of resources transfer cannot be considered as foreign aid. The foreign aid should have certain featured such as it should be with aim of economic development, welfare of recipient country and should have grant element, low interest rate and supportive for long term capital requirement.

Especially, aid funded under off-budget and mobilized by INGOs due to which there is lack of accountability and transparency, as a result effectiveness is low and accomplishment is delayed.In addition, aids are overloaded with conditions that limit autonomy of government in project implementation. Such condition attached with aid makes foreign aid not in the national interest. Moreover, political instability and the prolonged political transition affected foreign aid mobilization adversely.

\section{CONCLUSION}

Foreign aid is crucial factor to achieve higher and sustainable economic growth and development of Nepal. However, aid must be linked with sustainable growth and poverty reduction. Overall environment for aid required, aid coordination and harmonization and development output and outcomes must be closely linked. Government must attempts to be in driver's seat. Priority should be based on our potential and need. Absorptive capacity must be increased by enhancing the capacity of bureaucracy. In conclusion, aid is not bad and must be effectively utilized to attain national objective. 


\section{References}

National Planning Commission, Government of Nepal(.....).Development plan documents (Several Plandocuments). Kathmandu: Author.

Lekhi,R. K. (2005). The economics of development and planning. New Delhi: Kalyan Publishers.

Sigdel, B. (2004).Foreign aid in Nepal.Kathmandu.

Ministry of Finance, Government of Nepal.(.......).Various Economic surveys (various issues).Kathmandu: Author. 